the Health and Safety Executive's local employment medical adviser, while colleges of agriculture are able to give advice on appropriate changes in farming methods.

\section{ANTHONY SEATON}

Director,

Institute of Occupational Medicine,

Edinburgh EH8 9SU

1 Ramazzini B. De morbis artificum diatriba, 1713. Case W, transl. Chicago: Wright, 1940

Campbell JM. Acute symptoms following work with hay Br Med f 1932;ii:1143-4

Lowry T, Schuman LM. "Silo-filler's disease"-a syndrome caused by nitrogen dioxide. JAMA

1956;162:153-60

Thorax 1976:31:294-302

cuthbert OD, Brostoff J, Wraith DG, Brighton WD. "Barn allergy." Asthma and rhinitis due to storage mites. Clin Allergy 1979:9.229-36.

Cuthbert OD, Jeffrey IG, MCNeill HB, Wood J, Topping MD. Barn allergy among Scottish larmers. Clin Allergy 1984;14:197-206.

Lin PJ, Klaff LJ, Rose AG, Ferguson AD. Pulmonary effects of contact exposure to paraquat: a clinical and experimental study. Thorax 1979;34:150-60.

Pimental JC, Marques F. Vineyard sprayer's lung: a new occupational disease. Thorax $1969 ; 24: 678-88$

Grant IWB, Blythe W, Wardrop VE, Gordon RM, Pearson JCB, Mair A. Prevalence of farmer's lung in Scotland: a pilot study. Br Med J 1972;i:530-4.

Hapke EJ, Seal RME, Thomas GO. Farmer's lung. Thorax 1968:23:451-68

Emanuel DA, Wenzel FJ, Lawton BR. Pulmonary mycotoxicosis. Chest 1975;67:293-7.

Deaton A. Cross-reacting antibodies to Micropolyspora faeni in

Cuthbert OD Gordon MF. Ten year follow-up of farmers with farmer's lung Br I Ind Med 1983;40:173-6.

Morgan WKC, Seaton A. Occupational lung diseases. 2nd ed. Chapter 20. Philadelphia: W B Saunders, 1984

\section{Doctor to doctor}

In his preface to a booklet on writing and talking about patients recently published by the Nuffield Provincial Hospitals Trust Sir John Walton writes: "While communication between doctors on the one hand and patients and their relatives on the other is clearly a fundamental aspect of clinical medicine in all its branches, there is no doubt that communication between individual doctors often leaves much to be desired. Stories about misunderstandings and mistakes caused by careless clinical requests, notes, and letters are often recounted by doctors when they meet and talk 'shop' and are attributed, with some merriment, to curious idiosyncrasies of other doctors from which the gossipers feel themselves to be free. The fact that it is usually the patient rather than the doctor who may be most inconvenienced or even harmed by these mistakes is often overlooked."

Despite its obvious importance little research has been done or published on this subject. The time is now ripe for its further consideration because, within the current economic plight of the health service, united as a profession we may stand but disharmonious (in our planning and delivery of effective health care) we will fall. Given our obvious personally vested interests, how may we as individuals analyse and solve what is now a corporate problem? The simple but unhelpful answer is: with difficulty. Doctors are commonly very conscious of the errors made by their colleagues-but they are frequently unaware of the problems that they make themselves and, though this is forgivable, it does not allow progress.

Much of the problem may be traceable to attitudes acquired in medical training and then hardened during the stresses of daily medical practice. The need for prompt decision making commonly demands irreversible, snapshot judgments. This is an essential part of the immediacy of clinical practice, but it may be disadvantageous to the development and maintenance of amicable working relationships with colleagues-and especially if ill considered attitudes, mixed with too quick thinking, produce lingering prejudices that smoulder resentfully as unforgiven hurts. How, then, do we find a solution which will facilitate the healing of old wounds and foster the continually fresh growth of positive intraprofessional relations? We need to answer three questions.

Firstly, how does poor communication occur between doctors? The accounts of diverse personal experience so well presented in the excellent essays in the booklet clearly show the importance of courtesy among all parties. ${ }^{1}$ They also underline the need for clarity in written communication and, when referring a patient to a clinical or diagnostic department, the necessity for not only understanding the function of that department but also defining clearly the patient's problems and the questions to be answered. For the dialogue between colleagues to be effective an additional essential requirement is for the response to be equally legible, concise, relevant, and prompt. The value of face to face contact or telephoned conversation cannot be overemphasised.

Secondly, why does poor communication occur between doctors? A professional façade of social politeness can obscure the real answer. It is contained in these four words: attitudes, prejudices, resentment, and unappeasability. When I was a medical undergraduate one of my then respected (but, now I realise, obviously uninformed) medical teachers pronounced that general practice was the lowest form of clinical medicine. The damage that he and generations of his followers have done has spilled over to affect such apparently minor specialties as traumatic and orthopaedic surgery ("any general surgeon worth his salt can join two bones together"), psychiatry (you have to be mad to work there"), community medicine and mental handicap ("ha! ha!"), and even my own specialty of geriatric medicine ("I congratulate you on obtaining such a sinecure"). Thus lack of mutual esteem in this and other ways is one of the reasons why we have a problem.

Thirdly, what can be done about it? The solution is simple, but, because it requires an equally positive response, its application may be difficult-namely, despite blatant stupidities and provocations, forgive readily and strive to begin as a new person with each fresh encounter. This has, of course, 2000 years of authority behind it ${ }^{2}$ but there may be those who prefer an apparently modern approach. ${ }^{13}$

BRIAN LIVESLEY Consultant Physician

Department of the Health Care of the Elderly,

Dulwich Hospital (North Wing),

London SE22 8DF

1 Walton J, McLachlan G, eds. Doctor to doctor: writing and talking about patients; a collection of essays from a Nuffield working pary on communication. London: Nuffield Provincial Hospitals Trust,

${ }^{2}$ Holy Bible. Luke vi, 27-36.

${ }^{3}$ Casson J. Using words: verbal communication in industry. London: Casson, 1977. 